\title{
Anaerobowe zdolności motoryczne piłkarzy w wieku 9-15 lat objętych programem polish soccer skills
}

\section{Anaerobic motor skills of players aged 9-15 covered by the program of polish soccer skills}

Introduction. The key element of the footballer's training is the preparation of the physical performance. Long-term observations have shown tracks in the development of motor skills. In football, anaerobic abilities play a special role in athletic training. It can be assumed that only adequately measured motor skills are a guarantee of dynamic growth.

Aim of the study. The aim of this study is to assess the motor skills in the course of biological development of players aged 9-15 taking part in the Polish Soccer Skills programe and their numerical characteristics.

Material and methods. The study included 1131 players at the age of $9(n=189), 10(n=170)$, $11(n=183), 12(n=194), 13(n=124), 14(n=151), 15(n=120)$. The respondents participated in the Polish Soccer Skills programe and had varied professional experience. The starting speed over a distance of 5 meters, run over a distance of 20 meters, power of the lower limbs, agility run and growth were measured. The average descriptive statistics: (X), the minimum (min), maximum (max) and standard deviation (SD) were measured. The study was conducted in July and August 2014 in towns of Spała, Kleszczów and Wałcz.

Results and Conclusions. The study concluded that the level of anaerobic abilities are changing with the development of biological development of players taking part in the program of Polish Soccer Skills. The differences in the anaerobic abilities were observed across all age groups. 


\section{Wprowadzenie}

\section{Kultura fizyczna}

W literaturze przedmiotu napotykamy różne definicje kultury fizycznej. Zbigniew Krawczyk ujmuje „kulturę fizyczną jako względnie zintegrowany i utrwalony system zachowań w dziedzinie dbałości o rozwój fizyczny, sprawność ruchową, zdrowie, urodę, cielesną doskonałość i ekspresję człowieka, przebiegających według przyjętych w danej zbiorowości wzorców, a także rezultaty owych zachowań" (Krawczyk, 1995, s. 43). Maciej Demel i Alicja Skład przedstawiają kulturę fizyczną jako "wycinek rzeczywistości, na którym toczy się proces fizycznego wychowania" (Demel, Skład, 1986, s.13). Natomiast Zbigniew Naglak dokonał podziału kultury fizycznej ze względu na realizowane przez nią cele, wyróżniając kulturę fizyczną dzieci i młodzieży, osób dorosłych oraz fizjoterapię. Zwrócił również uwagę na istotę kultury fizycznej pisząc, że jedną z najistotniejszych części kultury fizycznej jest sport wraz ze współzawodnictwem o pierwszeństwo (Naglak, 2001).

\section{Sport}

Demel i Skład doprecyzowują definicję sportu ujmując ją w następujący sposób: „Sport to działalność uprawiana systematycznie, według pewnych reguł, odznaczająca się silnym pierwiastkiem współzawodnictwa oraz tendencją do osiągania coraz lepszych wyników, mająca na celu manifestację sprawności ruchowej" (Demel, Skład 1986, s. 13). Sport dzieli się na niekwalifikowany i kwalifikowany. Uprawianie sportu niekwalifikowanego, zwanego również rekreacyjnym, ma na celu utrzymanie aktywności i sprawności fizycznej, zdrowia psychicznego i dobrego samopoczucia (ustawa dnia 25 czerwca 2010 rok o sporcie), natomiast sportu kwalifikowanego - osiąganie jak najlepszych wyników na zawodach o zasięgu regionalnym, krajowym, światowym czy olimpijskim. Do osiągnięcia tego celu niezbędne jest odpowiednie przygotowanie ogólne i specjalne, które nabywa się przez długotrwały i intensywny trening sportowy (ustawa z 29 lipca 2005 roku o sporcie).

\section{Trening sportowy}

Trening sportowy według Sozańskiego to „wieloletni, specjalnie zorganizowany proces pedagogiczny, w ramach którego zawodnik uczy się techniki i taktyki swojej dyscypliny i doskonali je, kształtując sprawność fizyczną, a także cechy wolicjonalne i osobowość oraz nabywa wiedzę na temat prowadzonej przez siebie działalności sportowej" (Sozański, 1999, s. 73). Celem treningu według tego 
autora jest optymalizacja funkcji ustroju i rozwinięcie specyficznej adaptacji wysiłkowej, umożliwiającej uzyskiwanie maksymalnych wyników i osiągnięć w uprawianej specjalności ruchowej. Natomiast celem głównym treningu młodocianych jest stworzenie podstawy dla osiągnięć w wieku dojrzałym (Sozański, 1999). Proces treningowy złożony jest z następujących elementów: operator (F) który wyrażony jest funkcją charakteryzująca proces treningowy, wejście $(X)$ stanowiące całokształt odziaływań, jakim poddawany jest zawodnik, oddziaływanie otoczenia na efekt treningowy (Z), które dzieli się na wzmocnienia oraz zakłócenia, wyjście (Y) będące efektem treningu oraz parametry wyznaczające cele działania systemu $\left(Y^{*}\right)$. Wartości tych parametrów są skwantyfikowane i opisuje się ja za pomocą równania różniczkowego $Y=F\left(X, Z, Y, Y^{*}\right)$ (Kosendiak, 2010).

Trening sportowy składa się również ze struktury rzeczowej i czasowej, stanowiącej rozmieszczenie składowych procesu w układzie oraz sposoby ich wzajemnego podporządkowania i relacje między nimi oraz zasady sprzężenia w system funkcjonujący jako całość. Sposób funkcjonowania systemu stanowi łączny efekt funkcji poszczególnych elementów oraz struktury jako systemu (Sozański 1999, s. 80). Elementami struktury rzeczowej są: przygotowanie sprawnościowe, szybkościowe, siłowe, wytrzymałościowe, koordynacyjne, gibkościowo-skocznościowe, techniczne, taktyczne, psychiczne oraz przygotowanie teoretyczne, i intelektualne. Natomiast elementami struktury czasowej są między innymi etapy szkolenia: wszechstronny, ukierunkowany i specjalny.

\section{Przygotowanie zdolności motorycznych}

Przygotowywanie sprawności fizycznej polega na efektywnym rozwiązywaniu wszechstronnych zadań ruchowych odzwierciedlających wysoki poziom rozwoju narządów i funkcji ustroju, uwarunkowanych stopniem ukształtowania zdolności motorycznych określanych również mianem cech motorycznych, cech przygotowania fizycznego czy też cech przygotowania sprawnościowego (Sozański, 1999). Przygotowanie sprawności fizycznej obejmuje kształtowanie cech sprawnościowych, takich jak siła mięśniowa, szybkość, skoczność, wytrzymałość, gibkość i koordynacja ruchowa.

Wykonanie jakiegokolwiek ćwiczenia i pracy fizycznej wiąże się z potrzebą dostarczania energii (Osiński, 2003), dlatego zdolności motoryczne dzieli się na zdolności aerobowe wykorzystujące energię z tlenowych procesów metabolicznych oraz zdolności anaerobowe wykorzystujące energię z beztlenowych procesów metabolicznych. Piłka nożna należy do dyscyplin sportowych o dużych wysiłkach wytrzymałościowych, których źródłem energetycznym są mieszane procesy metaboliczne zarówno aerobowe, jak i anaerobowe. Wysiłki anaerobowe charakteryzują się dostarczaniem energii w krótkim czasie i są podstawowym źródłem energii w pracy o wysokiej intensywności do $90 \mathrm{~s} \mathrm{np.} \mathrm{w} \mathrm{biegach} \mathrm{krótkich.}$ Wysiłki aerobowe są źródłem energii w wysiłkach trwających z reguły powyżej 4 min. Wysiłki trwające od 90 s do 4 min nazywane są wysiłkami kombinowanymi lub jak wspomniano wcześniej mieszanymi (Osiński, 2003). 


\section{Źródła energii do gry w piłkę nożną}

Podczas gry w piłkę nożną energia powstaje w czterech fazach: beztlenowo-kwasomlekowej, beztlenowo - niekwasomlekowej, mieszanej oraz tlenowej. W strefie beztlenowo-kwasomlekowej występuje pobór energii, co ukazuje wielkość stężenia mleczanu we krwi na poziomie $14 \mathrm{mmol} / \mathrm{l}$ krwi. Pułap tlenowy wysoko sklasyfikowanego piłkarza wacha się na poziomie (VO2 max 45-65 ml/kg/ min). Dystans biegowy przebiegany w ciągu meczu w zależności od poziomu wytrenowania zawodnika wynosi od 8 do $12 \mathrm{~km}$. Przebiegnięcie $20 \%$ dystansu odbywa się przy wykorzystaniu wysiłków o sub- lub maksymalnej prędkości (start, zrywy). Natomiast odcinki biegowe 10-15-metrowe są najczęściej występującymi odcinkami w trakcie gry z częstotliwością 30-60 razy w ciągu meczu. Resztę przebiegniętego dystansu to: marsz, bieg w wolnym tempie, walka i wyskoki do piłki. Obecnie piłka nożna stawia wysokie wymagania i oczekuje się od trenerów kompleksowego przygotowania zawodnika pod względem sprawnościowym, technicznym, taktycznym i psychicznym. Doskonalenie sprawności fizycznej przebiega w ścisłym związku z rozwojem fizycznym i psychicznym. Tylko skojarzenie funkcjonalnego aparatu ruchu z układem cech somatycznych i innych układów daje możliwość osiągnięcia mistrzostwa sportowego (Sozański, Śledzewski 1993).

\section{Rozwój zdolności anaerobowych}

Na podstawie wieloletnich obserwacji ukazano, iż zdolności motoryczne mają swoiste tory rozwojowe. Udowodniono, że trening prowadzony $w$ tak zwanych okresach krytycznych jest dużo skuteczniejszy. Można przypuszczać, że właściwie zastosowany trening pod względem metod, form i środków z właściwymi obciążeniami stosowanymi w odpowiednim czasie jest gwarantem dynamicznego rozwoju. Brak znajomości zasad treningu sportowego jak i nieodpowiednie przygotowanie merytoryczne trenerów może powodować słabszy rozwój sportowca i brak optymalnego ukształtowania w procesie treningowym.

\section{Siła}

Siła definiowana przez Sozańskiego jest to „zdolność do pokonywania oporów zewnętrznych lub przeciwstawiania się im kosztem wysiłku mięśniowego" (Sozański, 1999, s. 85). Poziom siły zależny jest od wieku, płci i aktywności ruchowej. Krzywa rozwojowa chłopców wykazuje mniej dynamiczny wzrost niż dziewcząt. Zdolność ta znacznie wzrasta do około 20 roku życia, a następnie ulega stabilizacji w okolicy 30 roku życia. 


\section{Szybkość}

„Szybkość określana jest jako zdolność do wykonywania ruchów w najmniejszych dla danych warunków odcinkach czasu. Ocena ta przejawia się poprzez trzy składowe: czas reakcji, czas ruchu prostego oraz częstotliwość ruchów cyklicznych" (Sozański, 1999, s.106). Sozański i Śledzewski zwracają uwagę na czynniki, od których zależy szybkość lokomocyjna piłkarza w czasie gry, tj. poziomu siły i wytrzymałości, uwarunkowań genetycznych, proporcji budowy, techniki ruchu, uzdolnień ruchowych, a także od warunków zewnętrznych (Sozański, Śledzewski, 1993). W literaturze przyjmuje się, że rozwój w ontogenezie jest mocno zróżnicowany. Rozwój biologiczny ma ogromny wpływ na dyspozycje szybkościowe w młodszym wieku szkolnym (7-12 lat), natomiast w średnim wieku szkolnym (12-14 lat) można zaobserwować rozwój nierównomierny. Przyjmuje się, że kształtowanie szybkości w tym okresie musi być zindywidualizowane pod względem obciążeń i zadań. Okres dorastania (14-18 lat) w wyniku doskonalenie się funkcji układu nerwowego, oddychania i krążenia, a także przez rozwój i doskonalenie się funkcji układu mięśniowego, przyjmuje się jako najlepszy okres do kształtowania szybkości. W wieku 18-22 lat, czyli w okresie młodzieńczości następuje zakończenie procesów wzrostu i rozwoju i rozpoczyna się czas stabilizacji wszystkich układów organizmu człowieka (Osiński, 2003).

\section{Skoczność}

Skoczność jest wieloczynnikową funkcją dwóch podstawowych zdolności: szybkości i siły oraz budowy i proporcji ciała. Określa zdolność przemieszczania ciała w przestrzeni poprzez fazę lotu: najwyżej, najdalej, bądź też zależnie od zaistniałej sytuacji ruchowej określając moc zawodnika (Sozański, Śledziewski, 1993). W programie treningu ćwiczenia skocznościowe odgrywają szczególną rolę na etapie przygotowania wszechstronnego, kiedy ze względów rozwojowych nie jest wskazane stosowanie ćwiczeń z obciążeniem. Najlepsze warunki do kształtowania skoczności, tak zwane okresy krytyczne, u chłopców mieszczą się w wieku 13-15 lat natomiast najwyższy poziom w naturalnym rozwoju cecha ta osiąga w wieku 19-20 lat (Kapera, 1997, Talaga, 1995).

\section{Cel pracy}

Celem autorów niniejszego opracowania jest ocena zdolności motorycznych w przebiegu rozwoju biologicznego zawodników wieku 9-15 lat biorących udział w programie Polish Soccer Skills oraz ich charakterystyka liczbowa. Sformułowano następujące pytanie badawcze: Czy u osób objętych programem Polish Soccer Skills zmienia się poziom zdolności o charakterze anaerobowym wraz z wiekiem? 


\section{Materiał i metody badań}

Badaniem objęto 1131 zawodników w wieku: 9 lat $(n=189), 10$ lat $(n=170)$, 11 lat $(n=183), 12$ lat $(n=194), 13$ lat $(n=124), 14$ lat $(n=151), 15$ lat $(n=120)$. Respondenci uczestniczyli w programie Polish Soccer Skills i posiadali zróżnicowany staż startowy. Dokonano pomiaru szybkości startowej na dystansie $5 \mathrm{~m}$, biegu na dystansie $20 \mathrm{~m}$, pomiaru mocy kończyn dolnych, biegu zwinnościowego oraz wzrostu. Wykonano statystyki opisowe średnie (X), wartości minimalne (min.), maksymalne (max) oraz odchylenia standardowe (SD) badanych zdolności motorycznych. Badania zostały przeprowadzone w lipcu i sierpniu 2014 roku w miejscowościach Spała, Kleszczów i Wałcz. Wszyscy zawodnicy oraz trenerzy zostali poinformowani o procedurach prowadzonych badań oraz założeniach i celach programu Polish Soccer Skills.

\section{Polish Soccer Skills - www.polishsoccerskills.pl}

Program Polish Soccer Skills to projekt społeczny, którego celem jest rozwijanie i upowszechnianie profesjonalnego szkolenia piłkarskiego dzieci i młodzieży. Projekt jest realizowany na kilku uzupełniających się obszarach gry w piłkę nożną, co stanowi o jego kompleksowości. W ramach programu organizowane są wiosenne, letnie i zimowe obozy piłkarskie. Funkcjonowanie systemu oparte jest na wyselekcjonowaniu i promowaniu utalentowanych zawodników posiadających potencjał piłkarski. Każdego roku przeprowadzane są testy umiejętności piłkarskich u osób chętnych, mające na celu wyłonienie najzdolniejszej młodzieży w każdej kategorii wiekowej.

\section{Metodyka pomiaru wysokości ciała}

Wysokość ciała - badany stoi w pozycji wyprostowanej, ręce opuszczone swobodnie wzdłuż tułowia, głowa w pozycji frankfurckiej. Przy takim ustawieniu wysokość ciała została wyznaczona odległością między punktami vertex i basis.

\section{Metodyka pomiarów zdolności motorycznych}

Szybkość biegowa (startowa). Zmierzono czas przebiegnięcia odcinka $5 \mathrm{~m}$ z nabiegu $0,5 \mathrm{~m}$. Zastosowano pomiar $\mathrm{z}$ dokładnością do 0,001 s. Zawodnicy rozpoczynali pomiar ze startu wysokiego. Czas był mierzony za pomocą układu fotokomórek laserowych w układzie analogowym. Schemat pomiaru zaprezentowano 
na rysunku 1. Bieg był wykonywany dwukrotnie. W zestawieniach ujmowano wynik lepszy.

Szybkość biegowa (maksymalna). Zmierzono czas przebiegnięcia odcinka $20 \mathrm{~m}$ z nabiegu $0,5 \mathrm{~m}$. Pomiar został przeprowadzony z dokładnością do 0,001 s. Wszystkich badanych obowiązywał start wysoki. Czas był mierzony za pomocą układu fotokomórek laserowych w układzie analogowym. Schemat pomiaru zaprezentowano na rysunku 1. Bieg został wykonany dwukrotnie. Do opracowań zakwalifikowano lepszy wynik pomiaru.

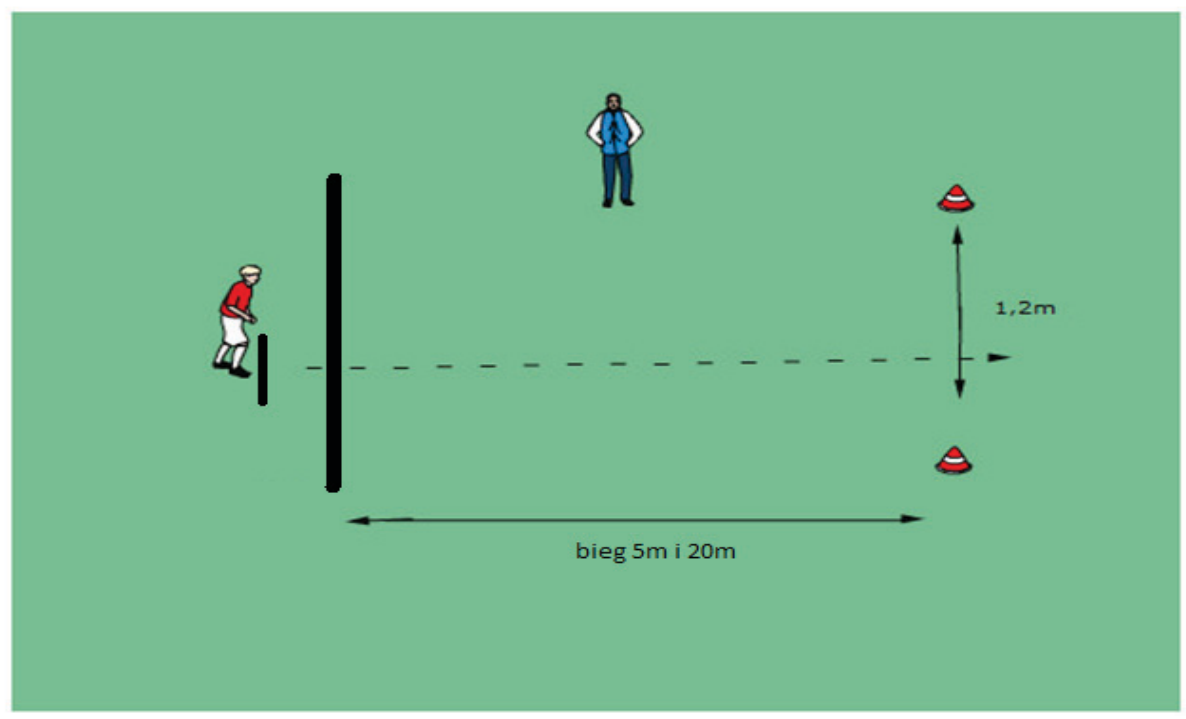

Rysunek 1. Pomiar szybkości startowej na odcinku 5 m i pomiar szybkości maksymalnej na odcinku $20 \mathrm{~m}$

Źródło: badania własne.

Moc kończyn dolnych. Dokonano pomiaru odległości skoku w dal z miejsca. Badany w półprzysiadzie, stopy ustawione równolegle, nogi lekko ugięte w stawach kolanowych, natomiast ramiona ugięte w stawach łokciowych. Następnie z półprzysiadu wykonując zamach ramionami wykonywał maksymalny skok poziomy w taki sposób, aby uzyskać jak najlepszy wynik. Schemat pomiaru przedstawiono na rysunku 2. Pomiar został podany z dokładnością do $1 \mathrm{~cm}$. Odległość jaką uzyskiwali zawodnicy mierzono od pierwszej części ciała, która miała styczność z podłożem. Badani wykonywali dwie próby. W zestawieniach uwzględniano wynik lepszy. 


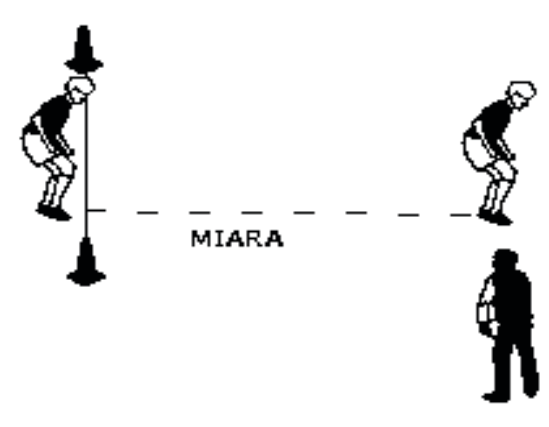

Rysunek 2. Pomiar mocy kończyn dolnych

Źródło: badania własne.

Zwinność. Dokonano pomiaru biegu zwinnościowego z nawrotami. Badany na sygnał startuje z pozycji wysokiej na odległość $5 \mathrm{~m}$, po przekroczeniu linii dwoma stopami dokonuje nawrotu i pokonuje dystans do linii startu. Schemat pomiaru zaprezentowano na rysunku 3 . Zawodnik pokonuje czterokrotnie dystans $5 \mathrm{~m}$ $z$ trzema nawrotami w jednej próbie. Do opracowań kwalifikowano wynik lepszy.

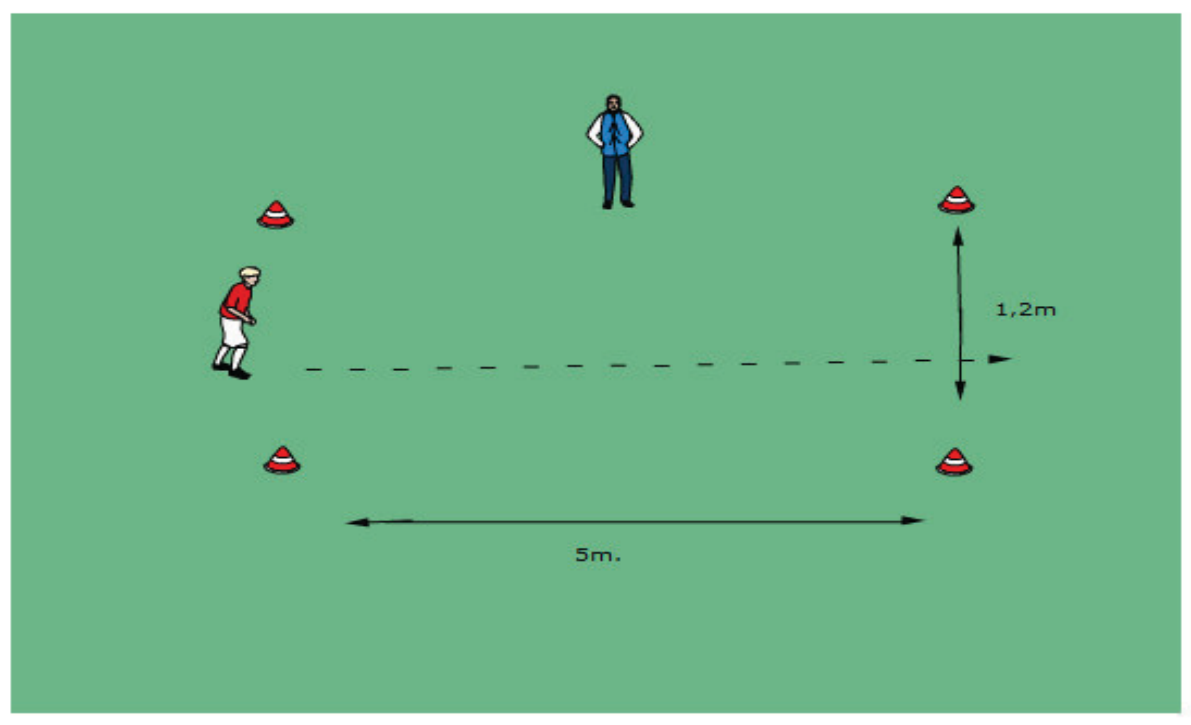

Rysunek 3. Próba biegu zwinnościowego 4 × 5 m

Źródło: badania własne. 


\section{Wyniki}

Zestawienie obrazujące charakterystykę liczbową wskaźników określających zdolności szybkościowe zamieszczono w tabeli 1. Zaobserwowano zmniejszanie się uzyskiwanych wyników na dystansie $5 \mathrm{~m}$ i $20 \mathrm{~m}$ wraz z wiekiem badanych. Można zaobserwować malejącą wartość wskaźnika prędkości wraz ze wzrostem wieku. Tendencja ta jest przedstawiona graficznie na wykresie 1.

Tabela 1. Zestawienie średnich oraz odchyleń standardowych prędkości uzyskanych w biegu na 5 i $20 \mathrm{~m}$

\begin{tabular}{|c|c|c|c|c|c|c|c|}
\hline Próba $5 \mathrm{~m}$ [s] & 9 lat & 10 lat & 11 lat & 12 lat & 13 lat & 14 lat & 15 lat \\
\hline$x$ & 1,299 & 1,294 & 1,231 & 1,202 & 1,175 & 1,121 & 1,098 \\
\hline $\min$ & 1,121 & 1,012 & 1,083 & 0,995 & 1,041 & 0,972 & 0,931 \\
\hline $\max$ & 1,572 & 1,611 & 1,421 & 1,471 & 1,405 & 1,312 & 1,354 \\
\hline SD & 0,098 & 0,106 & 0,077 & 0,084 & 0,074 & 0,069 & 0,083 \\
\hline Próba 20 m [s] & 9 lat & 10 lat & 11 lat & 12 lat & 13 lat & 14 lat & 15 lat \\
\hline$x$ & 4,089 & 4,002 & 3,823 & 3,699 & 3,56 & 3,377 & 3,296 \\
\hline $\min$ & 3,641 & 3,095 & 2,627 & 3,166 & 3,168 & 2,957 & 2,961 \\
\hline $\max$ & 4,701 & 4,693 & 6,771 & 4,392 & 4,224 & 4,032 & 3,704 \\
\hline SD & 0,217 & 0,326 & 0,382 & 0,221 & 0,202 & 0,206 & 0,174 \\
\hline
\end{tabular}

Źródło: badania własne.

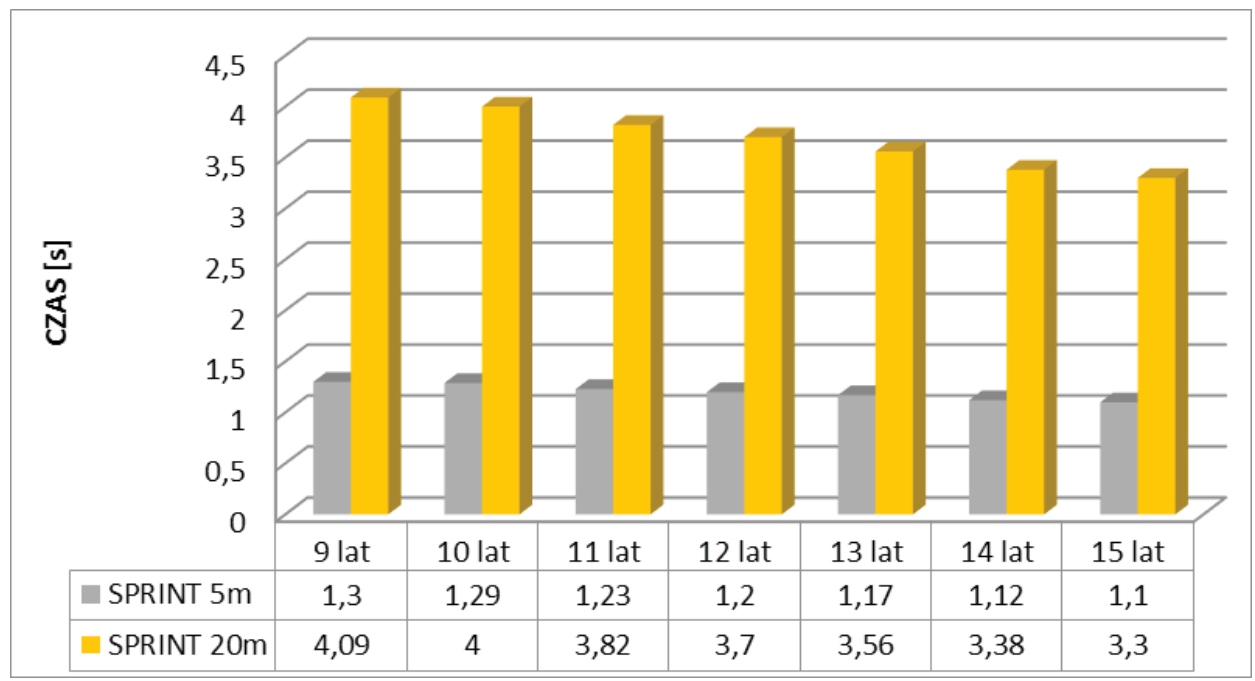

Wykres 1. Zdolności szybkościowe na dystansie 5 oraz 20 metrów z uwzględnieniem podziału na grupy wiekowe

Źródło: badania własne. 
Zestawienie odzwierciedlające średnie wyniki w biegu zwinnościowym zamieszczono w tabeli 2. Zaobserwowano malejącą tendencję wskaźnika wraz ze wzrostem wieku badanych grup i przedstawiono ją na wykresie 2. Okazało się również, że najwyższa wartość wskaźnika w biegu zwinnościowym została zaobserwowana w grupie 10-letnich zawodników, natomiast największe odchylenie standardowe występowało w kategorii 11-latków.

Tabela 2. Średnie i odchylenia standardowe testów sprawności o charakterze zwinnościowym badanych zawodników z podziałem na kategorie wiekowe

\begin{tabular}{|l|l|l|l|l|l|l|l|}
\hline Zwinność [s] & 9 lat & 10 lat & 11 lat & 12 lat & 13 lat & 14 lat & 15 lat \\
\hline$X$ & 7,408 & 7,376 & 7,098 & 6,917 & 6,674 & 6,441 & 6,39 \\
\hline $\min$ & 6,46 & 6,2 & 5,96 & 6,03 & 5,68 & 5,29 & 5,09 \\
\hline $\max$ & 9,14 & 9,61 & 9,09 & 8,76 & 8,07 & 7,65 & 8,43 \\
\hline SD & 0,525 & 0,555 & 0,634 & 0,535 & 0,476 & 0,452 & 0,521 \\
\hline
\end{tabular}

Źródło: badania własne.

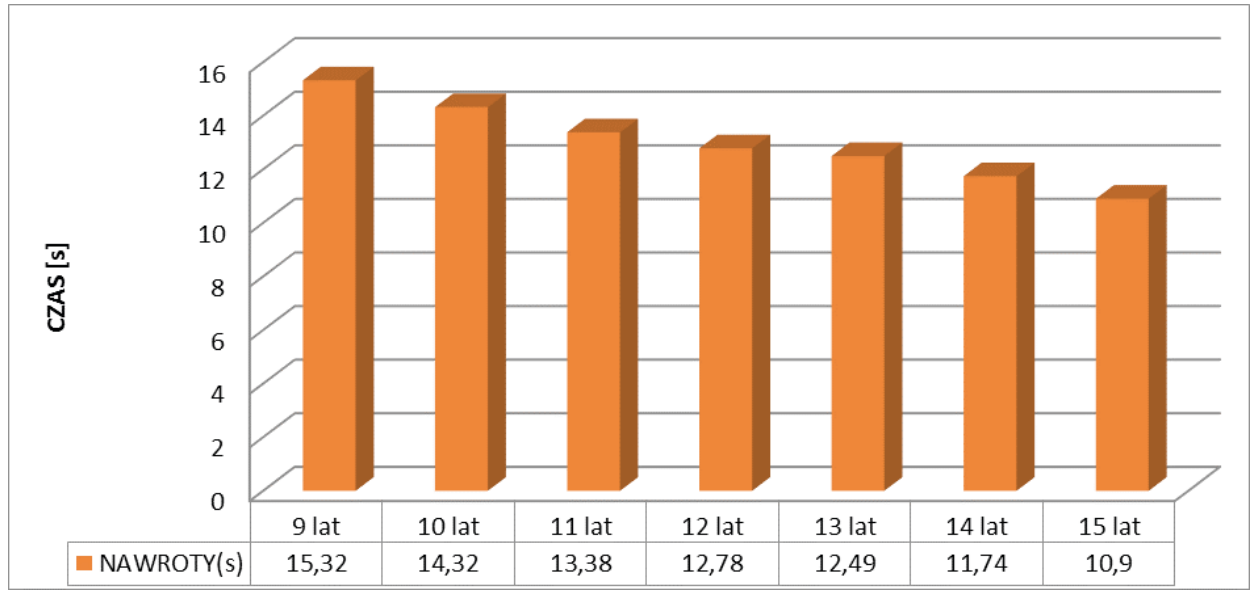

Wykres 2. Zdolności zwinnościowe z podziałem na kategorie wiekowe

Źródło: badania własne.

Zestawienie obrazujące wyniki próby szybkościowo-siłowej, jakim w badaniu była ocena mocy kończyn dolnych, przedstawia tabela 3. Zaobserwowano wzrost wskaźnika szybkościowo-siłowego w kolejnych kategoriach wiekowych. Tendencja ta odpowiada obserwacjom zauważonym w testach szybkości i biegu zwinnościowym. Graficznie została przedstawiona na wykresie 3. 
Tabela 3. Średnie wartości zdolności szybkościowo - siłowych badanych zawodników z uwzględnieniem podziału na kategorie wiekowe

\begin{tabular}{|l|c|c|c|c|c|c|c|}
\hline Moc [cm] & 9 lat & 10 lat & 11 lat & 12 lat & 13 lat & 14 lat & 15 lat \\
\hline $\mathrm{X}$ & 147,71 & 153,57 & 168,17 & 177,28 & 189,66 & 207,15 & 216,10 \\
\hline $\min$ & 102,00 & 105,00 & 115,00 & 124,00 & 137,00 & 163,00 & 180,00 \\
\hline $\max$ & 188,00 & 198,00 & 213,00 & 226,00 & 245,00 & 265,00 & 283,00 \\
\hline SD & 16,31 & 18,47 & 16,79 & 18,14 & 20,96 & 20,04 & 18,44 \\
\hline
\end{tabular}

Źródło: badania własne

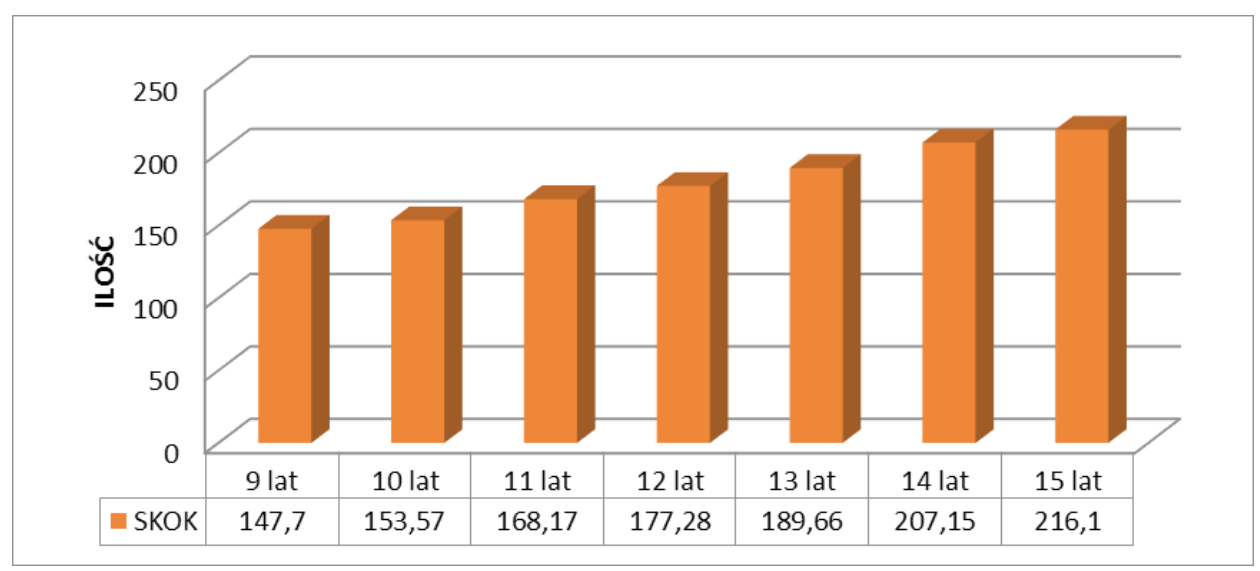

Wykres 3. Zdolności szybkościowo - siłowe z podziałem na kategorie wiekowe

Źródło: badania własne.

\section{Podsumowanie}

Sport jest pojmowany jako aktywność, której głównym celem jest podnoszenie sprawności fizycznej, uprawianej systematycznie, z określonymi regułami, przebiegającym we współzawodnictwie i dążącym do osiągania jak najlepszych wyników. Sformułowanie „systematycznie” oznacza trening odbywający się w dłuższym czasie, cyklicznie powtarzany i przygotowujący zawodnika do coraz większych obciążeń wysiłkowych. Natomiast „określone reguły” są to nie tylko zapisy regulaminowe obowiązujące $w$ danej dyscyplinie, ale również prawa rządzące biologicznym rozwojem organizmu. Tylko kompleksowe przygotowanie sprawnościowe, techniczne, taktyczne oraz przestrzeganie reguł i zasad obowiązujących w danej dyscyplinie sportowej prowadzi do optymalnego przygotowania organizmu człowieka i realizacji skomplikowanych zadań (Konarski, Strzelczyk, 2012).

Wyniki wybranych wskaźników zdolności motorycznych pokazały wzrost wszystkich parametrów. Zaobserwowano systematyczne zwiększanie wskaźników 
zdolności szybkościowo-siłowych oraz skracanie czasu wskaźników szybkościowych i zwinnościowych wraz z rozwojem biologicznym.

Analiza wartości wskaźników szybkości na dystansie $5 \mathrm{~m}$ była podstawą do oceny prędkości startowej i przyspieszenia. Próba ta wymagała od zawodników pełnej koncentracji na wykonywanych czynnościach. Można przyjąć, że jest ona niezbędnym elementem w kształtowaniu umiejętności piłkarskich i poszukiwanych zachowań na boisku. Zawodnik, który charakteryzuje się wysoką szybkością startową powiązaną z odpowiednią koncentracją na boisku, powinien uzyskać lepsze wyniki w tej próbie. Po przeanalizowaniu wyników stwierdzono, że najlepsze rezultaty uzyskiwali zawodnicy 15 -letni, natomiast najsłabsze zawodnicy 9-letni. Jest to zgodne $z$ systematycznym wzrostem badanej cechy wraz $z$ wiekiem.

Przy interpretacji wyników wskaźnika szybkości w biegu na dystansie $20 \mathrm{~m}$ okazało się, że potwierdziła się tendencja systematycznego skracania czasu wraz $z$ wiekiem badanych. Bieg na dystansie $20 \mathrm{~m}$ był podstawą do oceny zdolności do rozwinięcia i utrzymania prędkości maksymalnej.

Analiza wyników mocy kończyn dolnych wykazały podobne inklinacje do systematycznego wzrostu parametru wraz z wiekiem badanych jak próby szybkościowe. Najmniejsze średnie wartości uzyskiwały dzieci 9-letnie, natomiast najwyższą średnią wartość próby skocznościowej stwierdzono u 15-letniej młodzieży.

Również próby zwinnościowe przebiegały zgodnie z przyjętymi założeniami o zmniejszaniu się wartości czasu w uzyskiwanej próbie wraz z rozwojem biologicznym.

Optymalizacja i indywidualizacja treningu oraz kontrola obciążeń treningowych powinna być jednym z podstawowych zadań trenera. Tylko przez rzetelnie prowadzoną rejestrację obciążeń treningowych i kontrolę mamy szansę na harmonijny rozwój młodych sportowców. We współczesnej piłce nożnej tylko przez kompleksowe i wieloaspektowe ujęcie procesu szkolenia możemy doprowadzać młodego zawodnika do mistrzostwa sportowego. Proces ten powinien opierać się na indywidualnym doborze uwzględniającym tempo dojrzewania i stymulować rozwój biologiczny.

Przestrzeganie praw rządzących rozwojem biologicznym i ściśle sprecyzowane programy szkolenia pozwolą osiągnąć mistrzostwo sportowe, w pełni wykorzystując potencjalne możliwości zawodnika (Konarski, Strzelczyk 2012).

\section{Wnioski}

1. U zawodników objętych programem Polish Soccer Skills systematycznie zmienia się poziomzdolnościanaerobowych wrazzrozwojem biologicznym.

2. We wszystkich grupach wiekowych zaobserwowano zróżnicowanie zdolności anaerobowych.

3. W próbie określającej szybkość startową największą zmienność zanotowano w grupie 10-latków, natomiast najmniejszą w grupie 14-latków.

4. Po przeanalizowaniu wyników pomiaru szybkości na dystansie $20 \mathrm{~m}$ największą zmienność zanotowano w grupie 11-latków. 
5. Największą zmienność $w$ tej samej kategorii wiekowej zaobserwowano w biegu zwinnościowym.

6. Największe zróżnicowanie wskaźników siły eksplozywnej zanotowano w wieku 13 lat.

\section{Literatura}

Demel M., Skład A., 1986, Teoria wychowania fizycznego, PWN, Warszawa.

Kapera R., 1997, Piłka nożna - trening dzieci i młodzieży, Sprint, Warszawa.

Konarski J., Strzelczyk R., 2012, Zmienność profili wytrenowania motorycznego zawodników hokeja na trawie na wybranych etapach szkolenia, (w:) R. Strzelczyk, K. Karpowicz (red.), Etapizacja procesu szkolenia sportowego. Teoria i rzeczywistość, Monografie, nr 407, Wydawnictwo AWF w Poznaniu, Poznań, s. 154.

Kosendiak J., 2010, Projektowanie systemów treningowych jako ciąg zadań optymalizacyjnych, „Sport Wyczynowy", nr 3, s. 78-79.

Krawczyk Z., 1995, Socjologia kultury fizycznej, Wydawnictwo AWF, Warszawa.

Naglak Z., 2001, Teoria zespołowej gry sportowej. Kształcenie gracza, Wydawnictwo AWF we Wrocławiu, Wrocław.

Osiński W., 2003, Antropomotoryka, Wydawnictwo AWF w Poznaniu, Poznań.

Sozański H., 1999, Podstawy teorii treningu sportowego, Centralny Ośrodek Sportu, Warszawa.

Sozański H., Śledziewski D., 1993, Podstawy teorii treningu, Resortowe Centrum Metodyczno- Szkoleniowe Kultury Fizycznej i Sportu, Warszawa.

Talaga J., 1995, A-Z sprawności fizycznej, Ypsylon, Warszawa.

Ustawa o Sporcie kwalifikowanym, Dziennik Ustaw, nr 155, poz. 1298.

Ustawa o Sporcie, Dziennik Ustaw, nr 127, poz. 857, zm. Dziennik Ustaw z 2010 r., nr 151, poz. 1014. www.soccerskills.pl, data wejścia 2015-08-19. 